\title{
ANALISIS PENERAPAN PEMBIAYAAN MURABAHAH PADA FATWA NO. 84/DSN-MUI/XII/2012 BANK MUAMALAT KANTOR CABANG DARMO SURABAYA
}

\author{
Diah Putri Pravita Sari \\ Mahasiwa Program Studi S1 Ekonomi Islam - Fakultas Ekonomi dan Bisnis - Universitas \\ Airlangga \\ Email : diahputri166@gmail.com \\ Dr. Sri Herianingrum \\ Departemen Ekonomi Syariah-Fakultas Eonomi dan Bisnis-Universitas Airlangga \\ Email : sriheria@yahoo.co.id
}

\begin{abstract}
:
This study aims to determine the theoretical and practical application of murabahah about how the application by the Muamalat Bank branches of Darmo Surabaya. Methods of research of This study used a qualitative approach with the case study methods and descriptive analyzes. Then the researchers took the data in PT Bank Muamalat with some informants to be interviewed in depth, observed, and the data validated by triangulation methode.

These results indicate that the implementation of the bank Muamalat Murabahah darmo Surabaya branch office in according with the contained in the fatwa of murabahah which stated selling price to the buyer, then the flow of murabahah transaction can not be implemented in accordance with the provisions contained in fatwa because the field of business in Indonesia is still limited, it is not appropriate, next is the method in recognizing income / margin in the murabahah using the annuity method so that implementation of Muamalat bank financing is suitable with the fatwa number 84 .
\end{abstract}

Keywords : Murabahah Financing, flow of transaction, margin murabahah

\section{PENDAHULUAN}

\section{Latar Belakang Penelitian}

Banyak kritik masyarakat yang diarahkan kepada praktik murabahah di perbankan syariah, namun hal ini mengindikasikan bahwa produk murabahah direspon secara luas (Rahmawaty, 2007:193). Pada tataran aplikasinya, pembiayaan murabahah mengindikasikan adanya duplikasi pinjaman atau kredit dari bank konvensional, dengan realisasi perhitungan marjinnya mengacu pada bunga bank konvensional (Widodo, 2010:34). Perbankan syariah di Indonesia telah sepakat menggunakan bentuk kerjasama (murabahah dan mudharabah) sebagai sarana untuk merekonstruksi dan reorganisasi dalam dunia perbankan. Undang-undang perbankan Nomor 7 tahun 1992 dan peraturan pemerintah Nomor 72 tahun 1992 menyatakan bahwa bagi hasil pada sistem perbankan Syariah untuk membedakan dengan bank yang menggunakan instrumen bunga. Kemudian kini bank Syariah lahir sebagai salah satu alternatif terhadap masalah yang terkait dengan bunga bank, karena bank Syariah merupakan lembaga keuangan/ perbankan yang beroperasi dengan prinsip dasar tanpa 
menggunakan system bunga dan menggunakan penawaran sistem yang lain yang sesuai dengan prinsip Syariah.

Selama ini opini masyarakat tentang pembiayaan Murabahah adalah mereka menganggap bahwa hal itu sama dengan kredit pada bank konvensional, pada kenyataannya keduanya tidak sama. Selain itu penerapan metode pengakuan keuntungan pada pembiayaan murabahah di bank Syariah sebelum dikeluarkannya fatwa DSN masih menggunakan metode flat yang penerapannya kurang menghasilkan profit pada bank syariah walaupun dari segi syariah metode ini lebih kaffah, sebelum ditetapkannya fatwa DSN no 84 , penerapan tentang pembiayaan murabahah yang terdiri dari akad murabahah, alur transaksi pembiayaan, serta metode pengakuan keuntungan belum ada rujukan yang ideal sehingga terjadinya polemic masyarakat tentang murabahah pada bank syariah .

Peneliti ingin mengetahui bagaimana penerapan pembiayaan murabahah setelah dikeluarkannya fatwa dsn-mui yang baru tentang metode pengakuan keuntungan yang diterapkan di suatu bank Syariah supaya memberikan gambaran pada masyarakat yang masih berpendapat bahwa murabahah adalah kredit, Kemudian dari uraian masalah tersebut maka penulis mengambil judul Analisis Penerapan Pembiayaan Murabahah pada fatwa no. 84/DSNMUI/XII/2012 di Bank Muamalat Kantor Cabang Darmo Surabaya.

\section{Rumusan Masalah}

Berdasarkan uraian latar belakang di atas maka yang menjadi permasalahan dalam penelitian ini adalah :

Bagaimana

penerapan pembiayaan murabahah dengan fatwa DSN MUI No. 84/DSN-MUI/XII/2012 pada Bank Muamalat Kantor Cabang Darmo Surabaya?

\section{Tujuan Penelitian}

Tujuan dari penulisan ini adalah : Untuk menganalisis penerapan pembiayaan murabahah pada fatwa no.84/DSN-MUI/XII/2012 di Bank Muamalat Kantor Cabang Darmo Surabaya.

\section{TINJAUAN PUSTAKA}

\section{Landasan Teori}

Rahmawaty

(2007:188) mengemukakan bahwa "sejak awal tahun 1984 pembiayaan model murabahah di Pakistan mencapai sekitar 87 persen dari total pembiayaan dalam total investasi deposito profit and loss sharing (bagi hasil), sementara itu Dubai Islamic bank, bank terawal di sektor swasta, pembiayaan murabahah mencapai 82 persen dari total pembiayaan selama setahun 1989". Menurut saed (1996:77) "Islamic Development Bank (IDB), selama kurang lebih 10 tahun periode pembiayaan 73 persen dari seluruh pembiayaan adalah akad murabahah, yaitu dalam bentuk pembiayaan dagang luar negeri".

Ada sejumlah alasan mengapa murabahah begitu populer dalam perasi investasi perbankan syariah ialah karena 
murabahah merupakan suatu meknisme investasi jangka pendek dan dibandingkan dengan profit and loss sharing cukup memudahkan, mark-up dalam murabahah dapat ditetapkan demikian rupa sehingga memastikan bahwa bank dapat memperoleh keuntungan yang sebanding dengan keuntungan bank bebasis buga yang menjadi saingan bank-bank Islam, murabahah menjauhkan dari ketidak pastian yang ada pada pendapatan bisnis-bisnis dengan sistem profit and loss sharing dan murabahah tidak memungkinkan bank-bank Islam untuk mencampuri manajemen bisnis, karena bukanlah mitra dari nasabah, sebab hubungan mereka dalam murabahah adalah hubungan hutang-piutang dagang (Usmani, 2002:50).

\section{Pembiayaan Murabahah}

Murabahah berasal dari kata "Ribh" yang berarti keuntungan laba atau tambahan (Widodo, 2010:19). Menurut Fatwa Dewan Syariah Nasional-Majelis Ulama Indonesia (DSN-MUI) Nomor 04/DSNMUI/IV/2000 tentang murabahah. Pembiayaan murabahah adalah akad pembiayaan suatu barang dengan menegaskan harga belinya kepada pembeli dan pembeli membayarnya dengan harga yang lebih sebagai keuntungan yang disepakati.

Kamus Istilah Keuangan dan Perbankan Syariah yang diterbitkan Direktorat Perbankan Syariah, Bank Indonesia menjelaskan bahwa Ba'i
Murabahah (bai'ul murabahah) adalah jual beli barang pada harga asal dengan tambahan keuntungan yang disepakati. Dalam ba'i murabahah, penjual harus memberi tahu harga produk yang ia beli dan menetukan suatu tingkat keuntungan sebagai tambahannya.

Menurut Ibnu Rusyd dalam Antonio (2008:101) mengatakan bahwa bai' almurabahah adalah jual beli barang pada harga asal dengan tambahan keuntungan yang disepakati . dalam jual beli jenis ini, penjual harus memberitahu harga barang yang dibeli dan menentukan suatu tingkat keuntungan sebagai tambahannya.

Karim (2007:113), Murabahah adalah akad jual beli barang dengan menyatakan harga perolehan dan keuntungan (Marjin) yang disepakati oleh penjual dan pembeli. Dalam istilah teknis perbankan Syari'ah, murabahah ini diartikan sebagai suatu perjanjian yang disepakati antara Bank Syariah dengan Nasabah.

Dalam murabahah, penjual harus memberitahu harga produk yang dia beli dan menentukan suatu tingkat keuntungan sebagai tambahannya. Murabahah dapat dilakukan untuk pembelian dengan sistem pemesanan. Murabahah (al-bai' bi tsaman ajil) lebih dikenal sebagai murabahah saja. Murabahah, yang berasal dari kata ribhu (keuntungan), adalah transaksi jual-beli dimana bank menyebut jumlah keuntungannya. Bank bertindak sebagai penjual, sementara nasabah sebagai 
pembeli. Harga jual adalah harga beli bank dari pemasok ditambah keuntungan (margin) (Karim, 2004:87)

Dalam produk ini terjadi transaksi jual beli antara pembeli (nasabah) dan penjual (bank). Bank dalam hal ini membelikan barang yang dibutuhkan nasabah (nasabah yang menentukan spesifiksinya) dan menjualnya kepada nasabah dengan harga plus keuntungan. Jadi dari produk ini bank menerima profit atas jual beli murabahah. Harga pokoknya sama-sama diketahui dua belah pihak (Wiroso, 2009:160).

\section{Alur Transaksi pembiayaan Murabahah}

Berdasarkan pengertianpengertian yang telah dibahas sebelumnya, dapat dipahami bahwa murabahah adalah menjual suatu barang dengan menegaskan harga belinya kepada pembeli, dan pembeli membayarnya dengan harga lebih sebagai margin murabahah. Dalam transaksi jual beli terkadang unsur barang (cara dan syarat penyerahan barang) dan pembayaran (cara dan syarat pembayaran) digambarkan berdasarkan cara yang tidak sama.

Untuk menggambarkan alur transaksi murabahah secara umum dapat dilihat pada gambar 2.1. Berdasarkan gambar 2.1 di atas dapat dijelaskan sebagai berikut:

1. Antara pembeli dan penjual melakukan negoisasi tentang barang yang akan dibeli, syarat pembayaran dan syarat penyerahan barangnya.
Penjual memberitahukan harga perolehan barang, maka timbul kesepakatan yang tercantum dalam akad murabahah.

2. Barang yang akan diperjual-belikan kemudian menjadi milik penjual dan sudah ada dalam penguasaan penjual dalam hal harga, kualitas, dan jenisnya sudah diketahui penjual (supaya tidak timbul gharar). Setelah akad disepakati dilakukan penyerahan barang dari penjual kepada pembeli.

3. Cara pembayaran dilakukan sesuai dengan kesepakatan, baik secara tunai atau secara tanggun yaitu dengan cicilan atau angsuran.

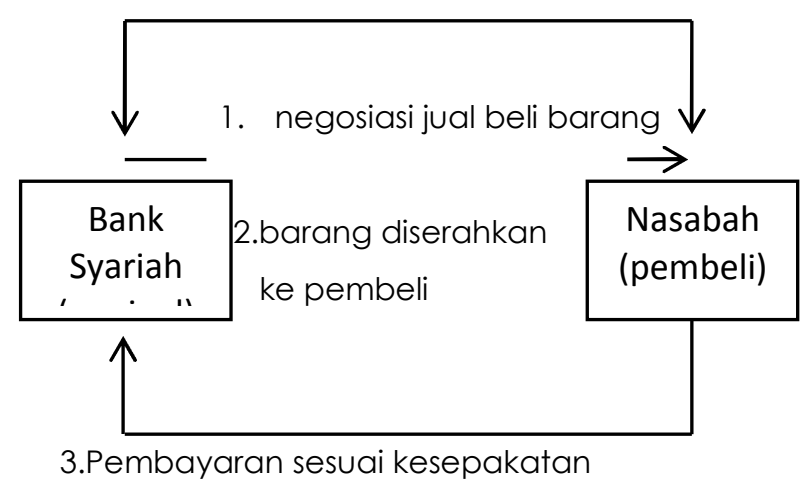

Gambar 2.1

\section{Alur Transaksi Murabahah menurut Wiroso}

Sumber: Wiroso (2009:163)

Fatwa DSN-MUI No. 84/DSN-MUI/XII/2012

Berikut adalah Fatwa DSN MUI no 84/DSN-MUI/XII/2012 yang dikeluarkan pada tanggal 12 Desember 2012.

\section{Metode Penetapan Margin Murabahah}

Menurut Al-ghazali dalam Karim (2008 : 326-327), saat ini bank syariah menggunakan metode anuitas dalam pengakuan pendapatan margin 
murabahah. Metode anuitas akan menguntungkan bagi bank syariah karena margin murabahah diakui diawal lebih besar dan akan menurun terus sampai pada angsuran terakhir.

Pengakuan laba atau marjin murabahah yang dihitung dengan menggunakan metode anuitas secara akuntansi didasarkan pada fakta bahwa keuntungan murabahah setiap tahun diperoleh atau dialokasikan berdasarkan perkalian antara saldo terutang dari pokok pinjaman diluar marjin laba dikalikan dengan marjin yang telah di tentukan yang secara implisit dikenakan atas pokok pinjaman itu. Ini memang sesuai untuk pinjam meminjam uang, tapi tidak sesuai untuk jual beli barang, dimana menurut prinsip syariah marjin laba dan pokok pinjaman itu menyatu sebagai piutang murabahah tangguhan yang tidak terpisahkan yang disebut Harga jual, Wibisana (2011 : 40).

\section{Proposisi}

Pelaksanaan

penerapan pembiayaan murabahah pada Bank Muamalat Kantor Cabang Darmo sesuai dengan fatwa DSN no. 84/DSNMUI/XII/2012.

\section{METODE PENELITIAN}

\section{Pendekatan Penelitian}

Penelitian yang dipilih penulis adalah penelitian kualitatif. Kualitatif dipilih karena untuk mengamati suatu fenomena yang terjadi dilingkungan masyarakat, mengumpulkan informasi serta menyajikan hasil penelitian yang telah diteliti secara kualitatif oleh penulis. Menurut Sugiyono (2012 : 9), metode penelitian kualitatif digunakan peneliti untuk memeliti pada kondisi obyek yang alamiah, (sebagai lawannya adalah eksperimen) dimana peneliti adalah sebagai instrumen kunci, teknik pengumpulan data/kualitatif, dan hasil penelitian kualitatif lebih menekankan makna pada generalisasi.

Metode yang digunakan dalam penelitian ini adalah studi kasus. Secara umum, studikasus merupakan strategi yang cocok apabila pokok pertanyaan suatu penelitian berkenaan dengan "how" dan "why", bila peneliti hanya memiliki sedikit peluanguntuk mengontrol peristiwa - peristiwa yang akan dielidiki, dan bilamana focus penelitiannya terletak pada fenomena kontemporer (masa kini) di dalam konteks kehidupan nyata (Yin,2012:1).

\section{Ruang Lingkup Penelitian}

Objek penelitian dilakukan pada PT Bank Muamalat yang berlokasi di J. Raya Darmo No. 81 Surabaya, Jawa Timur. Ruang lingkup penelitian ini hanya mencakup atas transaksi pembiayaan murabahah yang dilakukan oleh PT Bank Muamalat KC Darmo Surabaya. Ruang Lingkup penelitian yang dimaksud adalah dalam rangka menjawab rumusan masalah penelitian yaitu bagaimana penerapan pembiayaan murabahah yang diterapkan pada PT Bank Muamalat KC darmo. 


\section{Sumber data}

Sumber data yang digunakan untuk penelitian ini adalah data primer, yakni data yang diperoleh langsung dari informan yang bersangkutan. Menurut Wangsa dan Ming Kuan (2011:12), "Data primer adalah data utama yang penulis peroleh dari pihak-pihak yang bersangkutan pada perusahaan yang menjadi objek penelitian".

\section{Teknik pengumpulan data}

Dalam penelitian ini teknikn pengumpulan data dilakukan dengan cara sebagai berikut:

1) Wawancara

Wawancara

merupakan percakapan dengan maksud tertentu oleh dua pihak, yaitu pewawancara (interviewer) sebagai pengaju atau pemberi pertanyaan dan yang diwawancarai (interviewee) sebagai pemberi jawaban atas itu (Basrowi dan Suwandi, 2008 :127). Teknik wawancara yang digunakan dalam penelitian kualitatif adalah wawancara mendalam. Wawancara mendalam (in-depth interview) adalah proses memperoleh keterangan untuk tujuan penelitian dengan cara tanya jawab sambil bertatap muka antara pewawancara dengan informan dengan atau tanpa menggunakan pedoman (guide) wawancara, dimana pewawancara dan informan terlibat dalam kehidupan sosial yang relatif lama (Saeful, 2009:6).

2) Studi Literatur

$$
\text { Peneliti melakukan penelitian }
$$
dengan cara mengumpulkan dan mempelajari buku-buku yang berhubungan dengan akuntansi perbankan syariah terutama mengenai pembiayaan murabahah dan peraturanperaturan pemerintah yang berkaitan dengan hal tersebut.

\section{Teknik Validasi Data}

Validasi dari penelitian menggunakan uji kredibilitas. Uji kredibilitas data atau kepercayaan teerhadap data hasil penelitian kualitatif antara lain dilakukan dengan perpanjangan pengamatan, peningkatan ketekunan dalam penelitian, triangulasi, diskusi dengan teman sejawat, analisis kasus negatif, menggunakan bahan refrensi, dan membercheck. Pada penelitian ini teknik uji kredibilitas yang dilakukan adalah dengan menggunakan teknik triangulasi sumber yang diperoleh dari tiga informan penting. Penelitian ini juga menggunakan data pendukung, misalnya rekaman hasil wawancara, untuk membuktikan data yang telah diteliti.

\section{ANALISA DAN PEMBAHASAN}

\section{Pembiayaan Murabahah}

Salah satu pembiayaan di Bank Syariah adalah pembiayaan Murabahah , dan pembiayaan ini adalah menjadi pembiayaan dengan porsi terbesar dibandingkan dengan pembiayaan yang lain seperti mudarabah dan ijarah karena resiko nya lebih sedikit daripada pembiayaan lain bagi nasabah.

Pada pembiayaan murabahah harga jual itu di sepakati sebagai piutang murabahah yang terdiri dari porsi pokok 
dan marjin yang sebelum nya sudah di ketahui oleh penjual dan pembeli sebelum di akadkan. Piutang murabahah itu terdiri dari pokok (plafond) dan marjin ( keuntungan) yang sebelumnya sudah disepakati sebagai harga jual/ piutang murabahah yang akan dibukukan ke dalam pembukuan perusahaan.

\section{Alur Pembiayaan Murabahah}

Menurut informasi dari informan tentang masih belum sesuainya alur transaksi murabahah dengan ketentuan fatwa, dan kaidah fiqih Islam yang berlaku adalah karena di Indonesia ini bidang usahanya masih dibatasi, Lembaga Keuangan Syariah di Indonesia masih belum boleh memiliki usaha sendiri, misalnya showroom atau retail yang bisa menyediakan barang untuk nasabah. Apabila barang tersebut merupakan benda bergerak, maka bank harus menyediakan tempat penyimpanannya dan hal itu juga akan mempersulit bagi pihak bank, oleh karena itu untuk mengntisipasi kesulitan-kesulitan yang dihadapi oleh bank, maka dalam praktik perbankannya, transaksi murabahah dilakukan sebagai berikut:

1. Nasabah bertindak untuk dan atas nama bank sebagai wakil (wakalah) berdasarkan kuasa bank kepada nasabah untuk membeli barang langsung kepada supplier dengan spesifikasi yang telah disepakati antara pihak nasabah dengan supplier.

2. Nasabah bertindak untuk dan atas nama bank sebagai wakil(wakalah) berdasarkan kuasa bank kepada nasabah untuk melakukan pembayaran terhadap supplier.

3. Supplier bertindak untuk dan atas nama bank berdasarkan kuasa dari bank kepada supplier untuk melakukan penyerahan barang secara langsung kepada nasabah.

Mekanisme alur transaksi diatas yang disebut dengan pembiayaan murabahah telah dimasukkan kedalam instrumen yang disebut akad. Perjanjian kontrak atau akad yang digunakan bank melakukan proses pembiayaan murabahah dimana bank selaku penjual melakukan transaksi jual beli terhadap nasabah selaku pembeli dengan nilai jual sebesar harga pokok barang yang ditambahkan dengan margin yang telah disepakati oleh kedua belah pihak.

\section{Metode penetapan margin murabahah}

Dalam menetapkan margin murabahah pada Bank Muamalat dan Bank Syariah pada umumnya pihak Bank meenggunakan metode anuitas yang menyatakan harga perolehan/ harga jual yang terdiri dari pokok dan margin. Metode ini berbeda dengan metode flat, metode anuitas adalah metode yang diakui secara proporsional atas angsuran yang sistemnya adalah pada awal porsi pokok kecil, dan prsi margin besar, sehingga hal itu tidak akan membuat bank untuk mengalami kerugian karena di awal angsuran sebenarnya bank sudah menerima porsi margin yang besar, sehingga jika nasabah di suatu waktu 
mengalami pelunasan dipercepat atau mengalami kemacetan dalam pembiayaan bank sudah tidak lagi menanggung kerugian atas pendapatan dari pembiayaan murabahah, karena disini akad yang terjadi adalah jual-beli.

$$
\text { Metode penetapan magin }
$$

murabahah ditentukan berdasarkan harga perolehan barang, sebagai model penentuan penentuan harga jual pembiayaan murabahah dilakukan sesuai dengan konsep pembiayaan murabahah dari sudut pandang ekonomi Islam. Namun pada Bank Muamalat metode penetapan margin atas transaksi murabahah yang menggunakan metode anuitas ditentukan berdasarkan margin rata-rata bank syariah yang lain, hal ini menunjukan bahwa cara ini masih tidak lepas dari berlakunya tingkat suku bunga rata-rata dari bank konvensional. Meskipun demikian, konsep suku bunga pinjaman yang di jalankan pada bank konvensional berdasarkan nilai angsuran tidak diterapkan pada bank syariah, khususmya Bank Muamalat. Komposisi margin murabahah dan angsuran pokok murabahah yang berbeda setiap periode angsuran (anuitas), menunjukan bahwa transaksi murabahah pada Bank Muamalat sesuai dengan kaidah transaksi murabahah dalam perspektif ekonomi Islam, yaitu tetap menginginkan keuntungan sesuai dengan target pembiayaan, namun lebih adildan meminimalisasi kedzaliman atas penetapan margin murabahah yang berlebihan.
Metode yang ditetapkan leh Bank Muamalat terkait dengan pengakuan margin murabahah ini tidak semata-mata dilakukan untuk menetapkan keuntungan seperti halnya yang dilakukan oleh bank konvensional, melainkan untuk memberikan konsep pembiayaan yang mampu bersaing dengan konsep kredit yang diberikan oleh bank konvensional. Bank Syariah membuat rancangan pembiayaan murabaah bertujuan untuk menciptakan kebijakan pricing atas murabahah yang diharapkan mampu bersaing dengan nilai kredit pada bank konvnsional, hal ini dilakukan bukan untuk memberikan margin murabahah yang berdasarkansuku bunga, namun hingga sat ini perbankan syariah khususnya Bank Muamalat sudah mulai menentapkan margin murabahah sesuai dengan ketentuan yang berlaku.

\section{Analisis Penerapan Pembiayaan pada Bank Muamalat berdasarkan Fatwa no. 84/XII/2012}

Berdasarkan Fatwa no. 84/DSNMUI/XII/2012, maka dapat disimpulkan pelaksanaan penerapan pembiayaan murabahah pada Bank Muamalat Kantor Cabang Darmo Surabaya adalah sebagai berikut :

1. Murabahah menurut informan dari Bank Muamalat adalah adalah akad jual beli yang harga juanya telah diketahui oleh penjual dan pembeli sebelum perjanjian akad, sehingga pernyataan tersebut sesuai dengan pututsan Pertama ketentuan Umum 
poin no 3 yang menyatakan bahwa Murabahah adalah akad jual beli dengan menegaskan harga belinya kepada pembeli dan pembeli membayarnya dengan harga lebih sebagai keuntungan. Dan harga jual adalah piutang murabahah harus dibayarkan oleh pembeli kepada penjualn yang terdiri dari pokok (plafond) dan margin (keuntungan), dan sesuai dengan Putusan pertama ketentuan umum poin no 5 yaitu Harga Jual (tsaman) adalah Harga pokok ditambah keuntungan

2. Alur pembiayaan di Bank Muamalat adalah pertama nasabah memberitahukan kebutuhan barang yang di inginkan, kemudian bank sebagai penjual mentransfer vang ke rekening nasabah sesuai harga jual yang disepakati kepada nasabah sebagai pembeli untuk memberikan wakil / kuasa kepada nasabah untuk membeli barang yang dibutuhkan dengan pantauan dari pihak Bank. Jadi Bank disini bukan membelikan barang, melainkan menguasakan / mewakilkan pada nasabah untuk membelinya, sehingga hal tersebut masih belum sesuai dengan fatwa Putusan pertama ketentuan umum poin no 4 yang menyatakan bahwa At-Tanwil bi al-Murabahah (pembiayaan Murabahah adalah murabahah di lembaga keuangan syariah (LKS) dengan cara LKS membelikan barang sesuai dengan pesanan nasabah, kemudian LKS menjualnya kepada nasabah (setelah barang menjadi milik LKS) dengan pembayaran secara angsuran

3. Metode pengakuan keuntungan pada Bank Muamalat menggunakan Metode Anuitas, sehingga hal tersebut sesuai dengan Putusan ketiga ketentuan khusus no.4 yang menyatakan bahwa Metode pengakuan keuntungan at- tanwil bi al-Murabahah yang ashlah dalam masa pertumbuhan LKS adalah metode Anuitas.

4. Metode Anuitas adalah metode yang dipakai bank Muamalat dalam pembiayaan murabahah, harga pokok (plafond) dikalikan dengan marjin (keuntungan) adalah harga jual yang ditagih secara proporsional dengan ketentuan porsi pokok mengerucut besar kebawah, dan porsi marjin mengerucut kecil kebawah, sehingga pernyataan tersebut sesuai dengan Putusan pertama Ketentuan umum no 3 : Metode Anuitas ( Thariqah al- hisab alTanazzuliyyah/Thariqah alTanaqusiyyah) adalah pengakuan keuntungan yang dilakukan secara proporsional atas jumlah sisa harga pokok yang belum ditagih dengan mengalikan presentase keuntungan terhadap jumlah sisa harga pokok yang belum ditagih (al-atsman almutabaqqiyah). Selanjutnya Bank muamalat menjurnal pendapatan yang diperoleh dari pembiayaan murabahah sebagai piutang 
murabahah, dengan membukukan porsi pokok dan margin dalam jadwal angsuran, selanjutnya margin yang dibukukan oleh bank belum boleh diakui sebagai pendapatan murabahah, sebelum pembiayaan selesai, sehingga pernyataan tersebut sesuai dengan Putusan ketiga Ketuentuan Khusus no 5 yaitu Dalam hal LKS menggunakan metode pengakuan keuntungan at-tamwil bi al-Murabahah secara anuitas, porsi keuntungan harus ada selama jangka waktu angsuran ;keuntungan attamwil bi al-murabahah tidak boleh seluruhnya diakui sebelum pembiayaan murabahah berakhir/lunas dibayar.

\section{SIMPULAN DAN SARAN}

\section{Simpulan}

Simpulan yang dapat ditarik berdasarkan hasil penelitian yang dikaitkan dengan poin-poin ketetapan putusan yang sesuai dengan Fatwa DSN MUI nomor 84/DSN/MUI/XII/2012 pada tanggal 21 Desember 2012 di Jakarta, Indonesia adalah:

1. Murabahah adalah adalah akad jual beli yang harga juanya telah diketahui oleh penjual dan pembeli sebelum perjanjian akad.

2. Alur pembiayaan di Bank Muamalat adalah pertama nasabah memberitahukan kebutuhan barang yang di inginkan, kemudian bank sebagai penjual mentransfer vang ke rekening nasabah sesuai harga jual yang disepakati kepada nasabah sebagai pembeli untuk memberikan wakil / kuasa kepada nasabah untuk membeli barang yang dibutuhkan dengan pantavan dari pihak Bank. Jadi Bank disini bukan membelikan barang, melainkan menguasakan / mewakilkan pada nasabah untuk membelinya, sehingga hal tersebut masih belum sesuai dengan fatwa no 84.

3. Metode pengakuan keuntungan pada Bank Muamalat menggunakan Metode Anuitas, sehingga hal tersebut sesuai dengan fatwa no 84 yang menyatakan bahwa Metode pengakuan keuntungan at- tanwil bi al-Murabahah yang ashlah dalam masa pertumbuhan LKS adalah metode Anuitas.

\section{Saran}

Dari keseluruhan pembahasan dari tulisan ini saran yang diberikan penulis adalah:

1. Bahwa dalam perbankan, barangkali memiliki label Syariah saja, tidaklah cukup untuk menjadi suatu bank syariah. Pertama-tama dan terutama, sebuah institusi perbankan, entah itu dinamai Syariah atau tidak, perlu menjadi institusi yang lebih manusiawi, mampu membuat orang memiliki akses kepada dana berdasarkan syarat-syarat yang manusiawi, dan dengan biaya yang pantas

2. Tawaran konsep pricing atau penentuan harga jual dalam kontrak 
murabahah diharapkan dapat mencerminkan nilai syariah dalam perbankan syariah. Oleh karena hadirnya bank syariah di tengahtengah kita diharapkan mampu memecahkan segala problem ekonomi umat dengan paying Syariah

3. Perlu ada perbaikan dalam pelaksanaan alur transaksi murabahah yang diterapkan memalui perwakilan (wakalah), sehingga dapat mengangkat institusi bank syariah menjadi lebih menarik masyaakat termasuk yang masih ragu-ragu.

\section{DAFTAR PUSTAKA}

Antonio, M Syafi'i. 2008. DasarDasarManajemen Bank Syariah. Jakarta. Gema Insani Press.

Basrowi dan Suwandi. 2008. Memahami Penelitian Kualitatif. Jakarta: Rineka Cipta.

Dewan Syariah Nasional. 2012. Fatwa Dewan Syariah Nasional Metode Pengakuan Keuntungan Tanwil Bi AlMurabahah Di Lembaga Keuangan Syariah. Jakarta:Fatwa DSN-MUI No. 84.

Karim, Adiwarman. 2004. Bank Islam Analisis Fiqih dan Keuangan, Jakarta: III Indonesia.

Karim, Adiwarman. 2008. Bank Islam Analisis Figh dan Keuangan. Jakarta: Raja grafindo Persada.
Rahmawaty, Anita. 2007. "Ekonomi Syariah :Tinjauan Kritis Produk Murabahah Dalam Perbankan Syari"ah Di Indonesia". Jakarta: JurnalEkonomi Islam La Riba Vol. 1 No. 2.

Saeful Rahmat, Pupu. 2009. "Penelitian Kualitatif". Jakarta: Equilibrium Vol.5 No. 9.

Widodo, Sugeng. 2010. "Seluk Beluk Jual Beli Murabahah Perspektif Aplikatif" Yogyakarta.

Usmani, Rahmadi. 2002. Aspek-Aspek Hukum Perbankan Islam Indonesia. Cetakan Pertama, Bandung, IT Citra AdityaBakti.

Wiroso. 2005. Jual Beli Murabahah. Yogyakarta: UII Press, Cet. I.

Wiyono, Slamet dan Maulamin Taufan. 2012. "Memahami Akuntansi Syariah di Indonesia". Jakarta : Mitra Wacana Media.

Yin, Robert K. 2006. Studi Kasus :Desain dan Metode. Jakarta. PT. Raja Grafindo Persada. 